\title{
Design Studio: The Case for Social Entrepreneurship
}

\author{
NILOU VAKIL \\ University of Kansas
}

This paper outlines a participatory development strategy first tested and adopted in practice and now being reoriented as a studio design process. Two case studies from practice will be explored that provide unique strategies for empowering community. These crowdsourced projects pool resources and expertise in order to design and build projects that resist gentrification, stimulate investment, and build community. We then explore the translation of this process into an educational experience where students work directly with neighborhood residents to utilize the participatory actions of establishing a pro forma, acquiring land, securing financing, selecting professional engineers and contractors, and ultimately constructing the project all as larger components of community building.

The professional models of community development presented here offer an alternative to the traditional designer-client dichotomy and allow the once-clear boundary between architect and client to be redrawn. The potential of the educational model is more profound. It empowers students to chart a path that rejects a discipline rooted in form-making and aesthetics. It teaches the process of architectural design to be one of entrepreneurship. Students act as community organizers in setting up the framework in which community members are able to become active participants in their built environment.

\section{INTRODUCTION}

The architecture design studio is at the core of the architectural curriculum. ${ }^{1}$ Traditionally, it simulates a professional office environment with the studio instructor acting as the client by defining project requirements and providing feedback. While user needs are explored, the format of the studio necessitates the focus to be on client requirements. It is the client, after all, who will be paying the design fees. While the disconnect to real-world user interaction is apparent, this model has been lauded for its ability to engage students in the synthesis of knowledge delivered through support courses and the small-group interaction and potential one-on-one contact with instructors. The academic studio rejected the "sage on a stage" one-way dissemination of knowledge long before the notion of "flipped" classrooms made its way into higher education pedagogy. ${ }^{2}$

The studio process described here is being offered in conjunction with the Kansas City Design Center (KCDC). $\mathrm{KCDC}$ is a joint architecture and urban design facility run collaboratively by the University of Kansas and Kansas State University. Located in the heart of downtown Kansas City, KCDC is a nationally-recognized, nonprofit partnership among local civic leaders, professional designers, and the University programs, it is tasked with promoting excellence in the design of Kansas City's built environment. ${ }^{3}$ Like many university design centers, it seeks to partner and collaborate with community organizations, stakeholders and residents, local governments, and design professionals to promote excellence in urban design and the built environment.

Its studio coursework takes on a number of formats, however, the program is typically a year-long capstone experience investigating a particular design problem and has the ability to engage community stakeholders in ways that a typical studio may typically be constrained. As Kansas State University Professor Jason Brody states,

"Student-community service learning projects can be akin to Trojan horses. In throwing earnest and often naïve students into the thicket of community design we rely on a great number of residents and stakeholders and community officials to volunteer their perspectives. The student-community project is an opportunity for all to think big - not to abandon the constraints of a project but to hold decision making at bay while engaging students in a project's greater ambitions.... In this manner studentcommunity projects can at their best draw stakeholders together in frank discussion that might not be possible when the stakes are higher." ${ }^{4}$

It is the student-led Trojan horse that allows more audacious plans to be laid. Truly neutral parties to the intended outcome, the students bring little more than entrepreneurial spirit to the table. Their lack of ulterior motives combined with an enthusiasm that is contagious allows for seemingly-ridiculous projects to be considered and debated by neighbors, city officials, financial institutions, and other stakeholders. It is often out of this ridiculousness that is borne what one might call innovation.

The KU's fifth-year Social Entrepreneurship studio in conjunction with KCDC engaged neighborhood stakeholders along Prospect Avenue centered between the Key Coalition and Santa Fe neighborhoods of Kansas City to complete a revitalization study called Neighborhood 
Prospects. Students engaged neighborhood stakeholders in establishing areas of change and areas of stability, designing schematic infill housing prototypes, and making recommendations to best leverage the Transit Oriented Development zoning opportunities along Prospect. One key recommendation was to investigate self-development models that could empower neighborhood groups to participate in revitalization efforts.

The group looked to two entrepreneurial self-development case studies previously executed in Denver, Colorado as the basis for their proposal. Entrepreneurship is a process by which individuals pursue opportunities without regard to the resources they currently control..$^{5}$ The entrepreneurial architect, then, is one who is able to identify opportunities for change in our communities and independently takes constructive action.

The message for a final-year architecture student is significant: the de-coupling, or at least re-framing of the client role that may free the design professional from responding solely to the needs of paying clients, redraws boundaries that may allow us to address more complex challenges: climate change, crumbling infrastructure, lack of access to clean drinking water, food insecurity, disaster response, refugee shelter in areas of conflict, homelessness. Solutions to these and other challenges are rooted in the design and stewardship of the built environment. In an age of open-source architecture, crowdsourced information, and global interconnectedness, today's designer has never been better equipped to meet these challenges head-on.

Reconciling competing opportunities and constraints into a design studio that simultaneously serves the academic charge (client) and the larger community is seldom a straightforward endeavor. Students are challenged to imagine not only new physical environments but also new modes of architectural production to realize solutions that facilitate socially and environmentally responsible design.

Design solutions that aspire to goals such as these can rarely be achieved by any stand-alone building design and they cannot reside in the physical realm alone. The process of making architecture must be reexamined and reimagined to operate in a way that might be referred to as entrepreneurial.

\section{CASE STUDY: CHAMPA TERRACE}

The author's firm, in situ Design, was contacted by a group of neighbors living in the historic Curtis Park neighborhood of Denver, Colorado. A short walk from Denver's Central Business District, Curtis Park is one of the oldest neighborhoods in the city. It once contained the main thoroughfare connecting downtown to the since-relocated Stapleton Airport. Believing that this neighborhood would one day be the primary connector to the airport, city

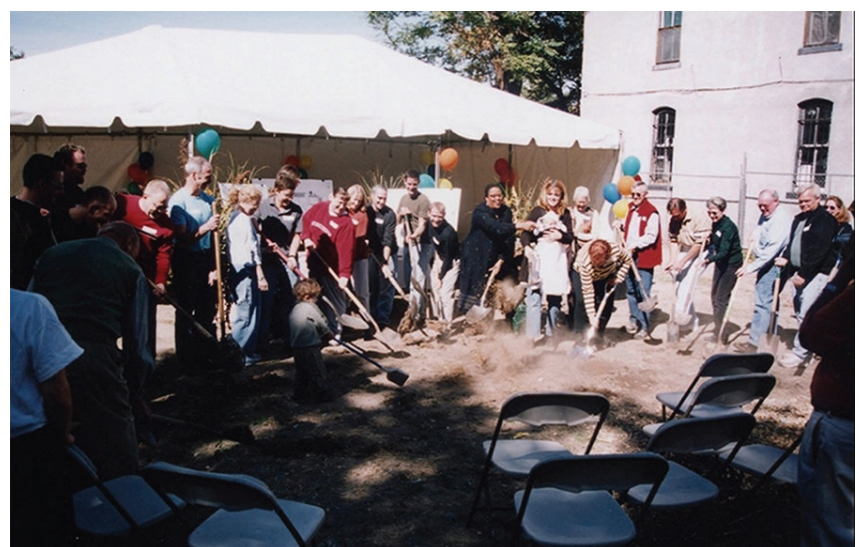

Figure 1. Community groundbreaking, in situ Design.

planners rezoned blocks of turn-of-the-century Victorian mansions, Italianate rowhomes, and quaint Queen Anne bungalows to a high to medium density commercial zone district. Two decades later, the explosion of growth south of the city and the relocation of the airport left a tree-lined walkable neighborhood largely-intact but with inappropriate zoning.

As increasing vibrancy and walkability began to transition Curtis Park into a desirable location ripe for redevelopment, outside developers began building what has since become referred to as "slot-homes." 6 These are side-by-side row homes that maximize allowable density by configuring units perpendicular to the street. The result is typically a bare wall presented to the street with any opportunity for a residential porch or stoop buried deep within the block. When neighbors learned of a developer's plan to construct such a 16-unit project on an empty lot between two historic homes, they began exploring opportunities that would allow them to tie up the land.

An initial group of eight families, all living within a few blocks of the property, formed a Limited Liability Company called Curtis Park Investors Group (CPIG) and purchased the lot for $\$ 40,000$. The group then began recruiting other interested parties within the neighborhood. They set out to construct a viable real estate development while protecting the neighborhood's historic character. As the venture gained momentum, town hall-style design workshops were held to manage the project. The resident group was from a diverse range of economic backgrounds that included such professions as a city planner, a teacher, an historian, a lawyer, and several residents who worked in the construction trades. They were brought together by concerns for the future of their neighborhood. A true example of crowdsourcing, these long-time neighborhood residents put their own homes up for collateral in order to secure a construction loan of $\$ 1$ million. This group of twenty-three neighbors recognized the power that came with organizing politically (figure 1). 


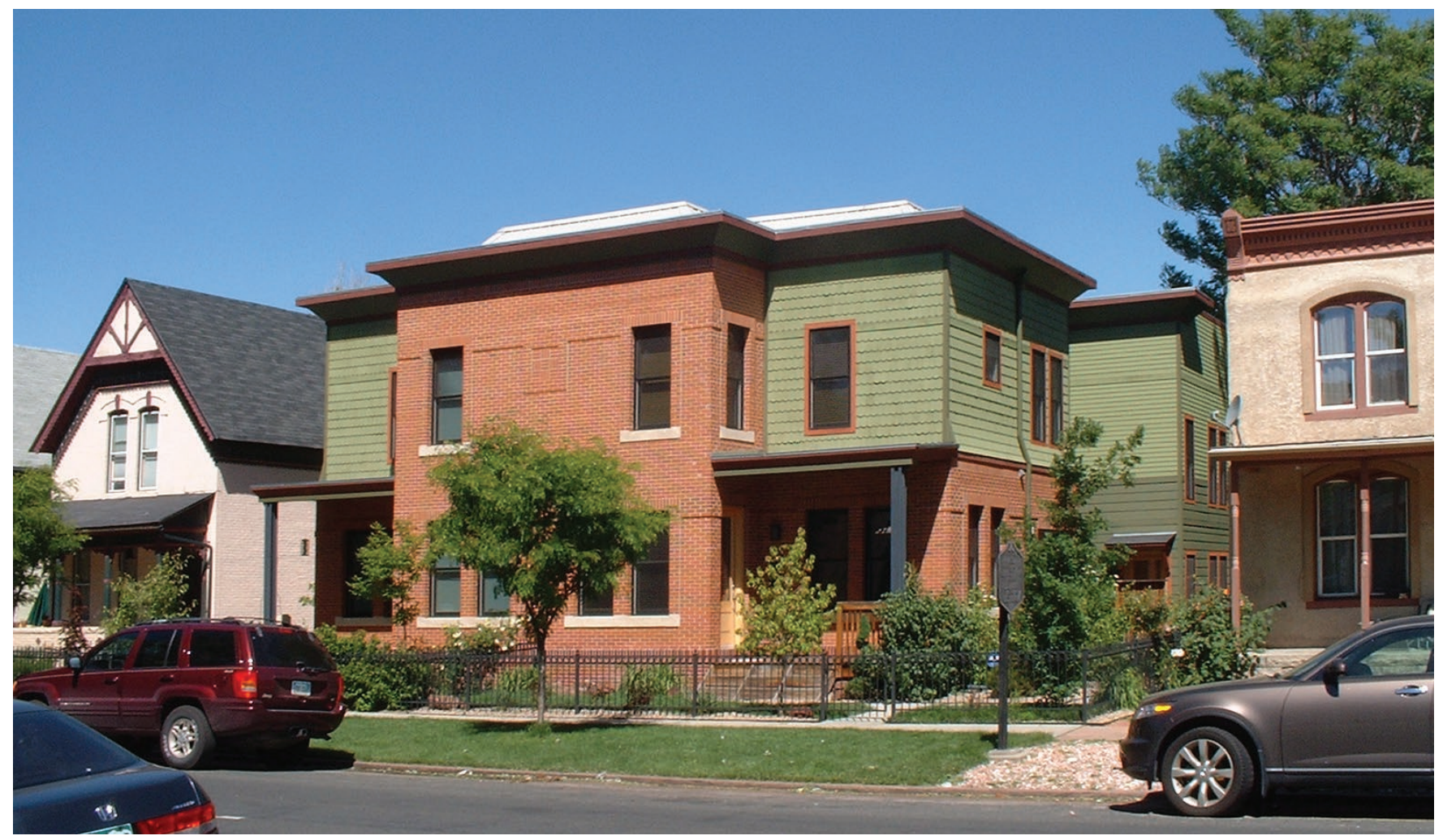

Figure 2. Champs Terrace Townhomes, in situ Design.

in situ Design worked with CPIG over the following months to develop a 4-unit townhouse project that would be called Champa Terrace. The solution maximizes the allowable site build-out while blending into a block of historic homes. Design features that enhance the residential character include front doors that all face the street, front porches that provide a pedestrian scale, and exposed steel columns that accent the porches and hint at modern interiors. The units have been designed to cluster service functions (powder, closet, laundry, stairs) along interior demising walls providing sound insulation that is essential to multi-family dwelling while maximizing the perimeter walls for large double-hung windows that have been selected to match historic windows throughout the neighborhood (figure 2).

\section{CASE STUDY: MERCHANTS ROW}

Champa Terrace was lauded in the local press for its proactive approach to community development. Feeling enfranchised and seeing the opportunity to replicate this development model, the group looked into rolling its returns into a second project. They investigated a vacant lot on an important corner that anchors an historic district. As additional neighbors became interested in joining the investment group, they realized they would need to establish a more sophisticated investment structure. A second LLC was established (CPIG II) that included both guarantors and non-guarantors of the loan. Within this framework, forty-two neighbors co-signed a construction loan.
This second self-development model is called Merchants Row Brownstones. This $\$ 2.5$ million multifamily housing development is modeled after a rowhome prototype common to the neighborhood. Sensitive of context, the group prioritized the relationship of form, mass, and scale to the surrounding buildings. Raised entry stoops all face the street with glass canopies that mimic the cable-stayed canopy of the adjacent 1890's structures. The entry stoop elevation is set at 5'-4" allowing for inhabitants to engage the passerby at the sidewalk while maintaining a comfortable separation between the public and private realms. This strategy, however, does not allow for the ceiling height required for a garage and thus units step up around a three-story lightwell that allows daylight to penetrate deep into the units. This alleviates the challenge of letting light into long interior units where side windows are typically not possible (figure 3 ).

While the land cost drove the development, it was important to the group that the project be configured in such a way that it could resist the homogenizing mechanisms of gentrification. Walk-out basements labeled as "flex-space" on city permit drawings sidestep parking requirements and provide a potential home office or live-work scenario. They are also easily configured into an affordable rental unit or granny flat. It was also important to the group that critical design concepts not be compromised by what they felt to be misguided zoning regulations or design guidelines. The carefully labeled "flex-space" is a case in point. 
Another procedural nuance that offered some resistance to the regulation of the built environment and was critical to the project's success was the categorization of the units as AttachedSingle-Family. Not only did this reduce professional liability associated with condominium developments but also allowed the group to avoid the creation of a homeowner's association. One requirement of this classification is that each unit must maintain its own lateral bracing; that is, should one unit's lateral bracing be compromised, adjacent units must maintain their own lateral stability. This is made visible in the design by exposing the steel cross bracing in the three-story lightwells (figure 3).

Also, the primary feature of the exterior is a reinterpretation of the historic bay: a three-story mullionless curtainwall (figure 3). Despite historic district design guidelines that require punched windows in a solid field, the group was able to convince the design review board, Denver's Landmark Commission, that the pattern of frosted and clear glass configured in the proportions of window openings in the neighborhood met the intent of the guidelines. Stepped out from the façade, side windows at the bay frame views to downtown while translucent bays glow to activate the street with vitality at night. Convincing the group to challenge the literal reading of the historic district design guidelines was no small accomplishment given that many of the investors have an affinity for historic preservation that borders on militant.

Also significant in swaying the design board's ruling was the fact that many of the investor-residents had been involved with establishing the historic district. The glass bays also reflect a certain do-it-yourself ingenuity. The components are all off-the-shelf and designed by the structural engineer ${ }^{7}$ (figure 4). The risk in configuring such an assembly with no clear warranty and the lack of clarity in assigning responsibility for resistance to moisture intrusion would cause most developers to pull back. The neighborhood group, perhaps naively, greeted this calculated risk with enthusiasm.

This project, like the earlier example, sold out soon after the completion of construction. The pride the group took in witnessing a cultural enterprise emerge from their shared ideas and resources was evident. Open house events and tours were more of a neighborhood celebration than marketing event and inexplicably extended even after all the units were sold. Guarantor investors received a pref return as the project closed out and non-guarantors received their proceeds soon after. Several investors, in various structures and configurations, continue to roll over development proceeds into neighborhood investments of various scales.

\section{KANSAS CITY SELF-DEVELOPMENT PROJECT}

A new group of students from KU's Social Entrepreneurship Studio is now taking recommendations from the Neighborhood Prospects study completed with KCDC. They are assembling a group with the capacity to execute

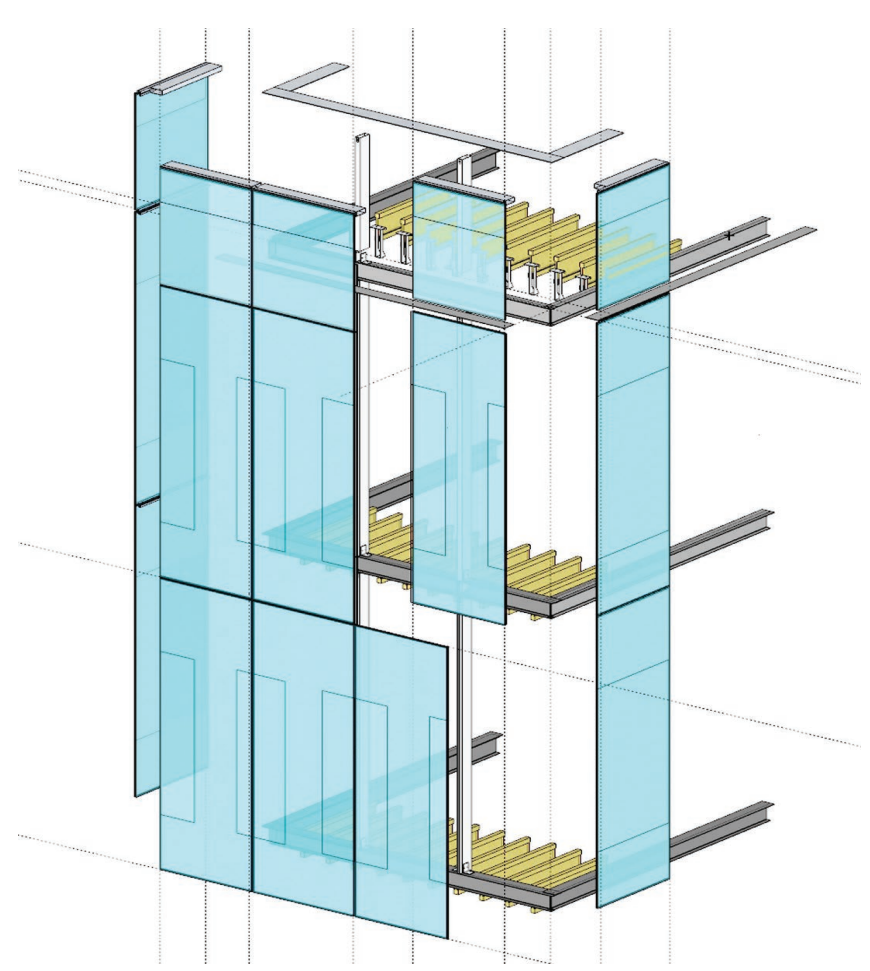

Figure 3. Merchants Row Brownstones - glass bay structure.

a self-development in the Santa Fe Neighborhood of Kansas City utilizing the case studies outlined above as a model (figure 5).

This project has the potential to demonstrate a city-wide strategy for the revitalization of underserved communities through the notion of shared economy. In April of 2017, Kansas City voters were asked to approve a one-eighth-cent sales tax to spur economic development in the city's most blighted neighborhoods. Spearheaded by the Urban Summit, partner nonprofits and area churches led the charge to have the initiative placed on the city ballot. ${ }^{8}$ The initiative would also compete with three general obligation bond questions that supported infrastructure improvements. The initiative thus brought considerable opposition from Mayor Sly James' office who feared voters would reject pleas for funding parts of the city where they don't live and jeopardizing all four tax questions. ${ }^{9}$

The Central City Economic Development Sales Tax is to be in place for 10 years and provides a projected revenue of $\$ 8.6$ - 10 million each year. This citywide tax would only be utilized in an area bounded by Ninth Street to the north, Gregory Boulevard to the south, the Paseo to the west and Indiana Avenue to the east. Essentially, Kansas City's traditionally most underserved neighborhoods. An appointed board made up of designees of such entities as the Mayor's office, the school board, city council, etc. will oversee the distribution of the tax revenues. The author, with affiliated faculty from the Kansas City Design Center (KCDC), engaged citizenry from within this established boundary in order to respond to the city's Request for Proposals. 


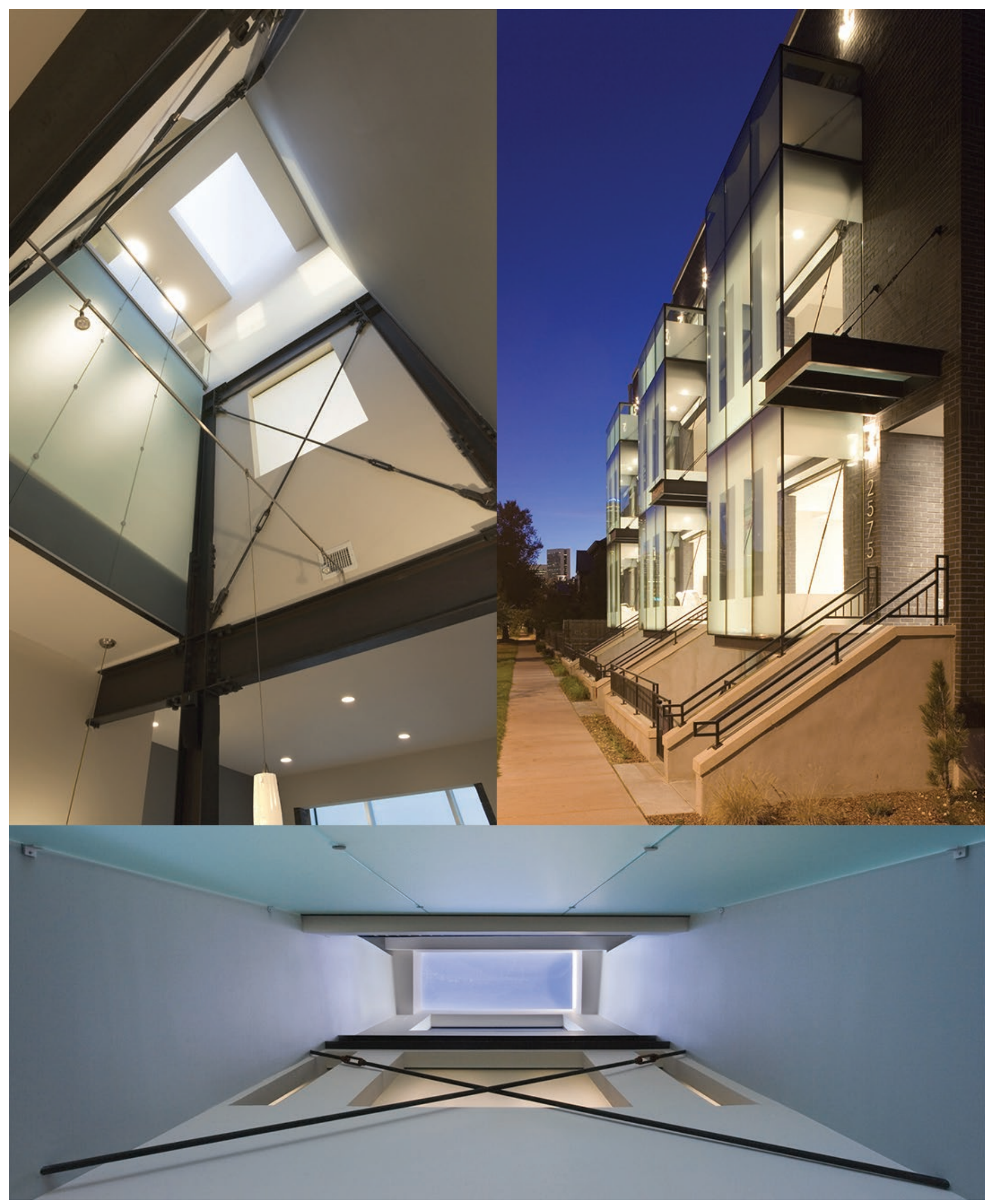

Figure 4. Merchants Row Brownstones - glass bays - three story light wells, in situ Design. 
A sales tax is often hurtful to the poor, ${ }^{10}$ however, rather than reinvesting the tax revenue in neighborhoods that are wellpositioned, the revenue from this initiative will be limited to an area identified with high crime, unemployment, dilapidated housing stock, and a lack of development. Leaders of the initiative cited two reasons why this tax makes sense: 1 . When a city's core is healthy, the entire city is healthy; and, 2 . Residents of these neighborhoods have consistently supported similar tax initiatives that funded major projects outside the core, including a \$1billion airport improvement project."1 The vote was telling. Most neighborhoods voted in favor of the tax despite the reality that it would not directly affect them. ${ }^{12}$

\section{NEIGHBORHOOD PROSPECTS: A STUDENT- ORGANIZED DEVELOPMENT PROCESS}

The first iteration of a response to the city's Request for Proposals process has been completed. The proposed self-development project is for a 6-unit townhome project priced in the range of $\$ 170,000$. Various solutions have been tested to arrive at a viable development model. Schematic financial analysis utilized construction costs provided by a local contractor. Single family homes were estimated to cost in the range of $\$ 140 /$ sf while the efficiencies of a multifamily structure brought the cost down to about \$110/sf. All proposed options were market-driven and assumed at least $10 \%$ profit. This resulted in the required sales price for single-family homes to be approximately $\$ 330,000$ while townhomes would need to yield a sales price of $\$ 170,000$.

This difference is significant. Not only is a home price above $\$ 300,000$ not compatible with comparable prices in the neighborhood, homes in this price range would almost exclusively be marketed to buyers from outside the community. Units for sale at $\$ 170,000$ could serve home buyers with a desire to remain in the community. It is estimated such units would yield monthly payments of $\$ 750$ to $\$ 850$. This is well within the range of apartment rental rates within the neighborhood. The goal of creating affordable housing is elusive in a neighborhood that has suffered disinvestment that has resulted in depressed property values. Typically, affordable housing can be defined as being able to attain housing at no more than $30 \%$ of one's income. Using this standard, a two-income family earning the Area Median Income of $\$ 22,000$ could comfortably maintain these anticipated mortgage payments.

As of present time, the Central City Economic Development Sales Tax Board had not yet selected finalist respondents to their Request for Proposals. However, it is necessary to delve deeper into the specifics of this self-development proposal here. The multifamily project outlined in our submittal is a 6 -unit townhouse project. The parcels that make up our proposed site are controlled by the city and thus we assume land acquisition will be accomplished at nearly zero cost. Six units approximately 900 $-1,200$ sf and a projected construction cost of $\$ 110 /$ sf equate to a hard construction cost of $\$ 660,000$. Soft costs, contingency, and financing bring total development costs to $\$ 855,549$. We

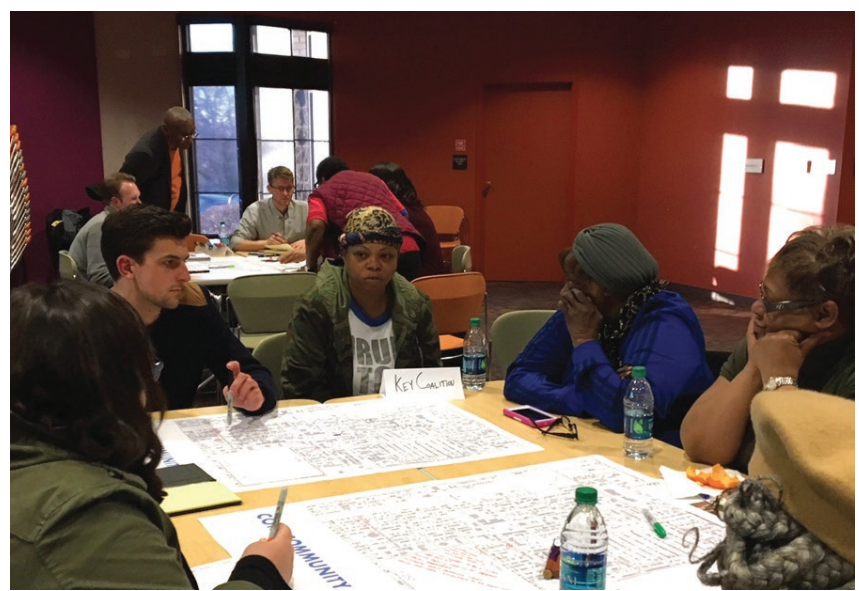

Figure 5. KCDC-led community design workshop, KCDC.

have suggested an equity requirement of $\$ 163,273$ to be split, with half of the amount being contributed from the tax fund and the remaining half being achieved with resident investment. Thus, our request to the city is for $\$ 81,000$ in funding.

Assuming twenty investors, this scheme results in residents being able to participate in real estate development within their own neighborhood for approximately a $\$ 4,000$ buy-in. At a sales cost of $\$ 170,000$ and a profit of $12 \%$, each investor will receive a $\$ 1,081$ payout per share.

\section{CONCLUSION}

The Social Entrepreneurship Studio at the University of Kansas in conjunction with the Kansas City Design Center (KCDC) provides a yearlong investigation that provides a studio experience that is immersive in nature. Using a real site and real clients, the studio is run as a practicum. Its intent is to offer real-world experience while being afforded the space to approach the design problems presented with rigorous and critical thought. Like all entrepreneurial ventures, the process is "contingent" in nature.

Unlike a self-contained introverted studio that has a predetermined and well-defined scope, this engagement is set up to confront he unforeseen and uncontrollable aspects of architectural practice. The goal is to empower students with the improvisational intelligence necessary to navigate the unknown, and unknowable, that define all real-world endeavors. This approach implicitly embraces the assumption that design extends beyond formal aesthetic concerns. As such, a contingent pedagogy is employed, one that confronts students with an architecture problem of indeterminate scope in order to expand the potential field of operation beyond conventional academic limits. ${ }^{13}$

The potential of this project is exciting, not only because it implies inclusive participatory input from those affected by a development project but also because it implies that participants have an opportunity to share in the increased value that is 
brought to their neighborhoods by real estate development. The value created by architectural production has been one of the most stable and well-performing strategies for growing wealth. Yet, participation in real estate development is an impossibility for the vast majority of the population. Through entrepreneurial design thinking, architects have the potential to ease the barriers to such community investment opportunities and share in the transformative act of building community.

Students move away from these projects understanding the true value of design. The architecture school studio is often considered to be something of an academic exercise. Students are encouraged to experiment but with little risk. Typically, they are able to move on to the next imaginary site and imaginary client. This studio model arms students with the entrepreneurial spirit to mobilize neighborhoods. Blurring the line between designer and political organizer, students are better prepared to be leaders in their communities and thus in their firms. They enter practice with the belief that they can work critically and strategically to restructure a world they cannot completely remake.

\section{ENDNOTES}

1 Ernest L. Boyer and Lee D. Mitgang, Building Community: A New Future for Architecture Education and Practice (Stanford, CA: Carnegie Foundation for the Advancement of Teaching, 1996).

2 Eric Mazur, "Farewell, Lecture?" Science 323 (January 2009): 50-51.

3 Kansas City Design Center, "About," accessed July 1, 2018. http://www.kcdesigncenter.org/aboutkcdc/.

4 Neighborhood Prospects, report (Kansas City: Kansas City Design Center, 2018).

5 Howard H. Stevenson and J.C. Jarillo, A Paradigm of Entrepreneurship: Entrepreneurial Management 1 (Lausanne: International Institute for Management Development. Research and Development, 1992).

6 Andrew Kenny, "Denver Shows off Plans to Replace Infamous 'Slot Home,'" Denverite, November 29, 2017. https://denverite.com/2017/11/29/ replace-dreaded-denver-slot-home/.

7 Christopher O'Hara, "Structural Glazing Systems," Builder News Magazine, (September 2006): 20-22.

8 Diane Stafford, "Here's Basic Information about the Sales Tax Question on Kansas City's April 4 Ballot," The Kansas City Star, March 9, 2017. https://www. kansascity.com/news/local/article137499708.html.

9 Diane Stafford, "Sales Tax Advocates Say It's Time for All of KC to Support Inner City Redevelopment," The Kansas City Star, March 21, 2017. https://www.kansascity.com/news/business/development/article139961143.html.

10 Eric Kades, "Giving Credit Where Credit is Due: Reducing Inequality with a Progressive State Tax Credit," Faculty Publications page, William \& Mary Law School scholarship repository, January 2016, accessed August 8, 2018. http:// scholarship.law.wm.edu/facpubs/1830.

11 Ron Knox, “Can Kansas City Come Together?,” Citylab, May 2, 2017. https://www. citylab.com/solutions/2017/05/can-kansas-city-come-together/525012/.

12 Knox, "Can Kansas City Come Together?"

13 Michael Huges, "Constructing a Contingent Pedagogy," in Architecture Live Projects: Pedagogy into Practice, eds., Harriet Harriss and Lynette Widder (London: Routledge, 2014). 